\title{
Review \\ A Review of Potential Role of Capsule Endoscopy in the Work-Up for Chemotherapy-Induced Diarrhea
}

\author{
Takayuki Ando *, Miho Sakumura, Hiroshi Mihara, Haruka Fujinami $\mathbb{D}$ and Ichiro Yasuda
}

Citation: Ando, T.; Sakumura, M.; Mihara, H.; Fujinami, H.; Yasuda, I. A Review of Potential Role of Capsule Endoscopy in the Work-Up for Chemotherapy-Induced Diarrhea. Healthcare 2022, 10, 218. https:// doi.org/10.3390/healthcare10020218

Academic Editors: Saleh A. Naser and Edward J. Pavlik

Received: 27 November 2021

Accepted: 21 January 2022

Published: 24 January 2022

Publisher's Note: MDPI stays neutral with regard to jurisdictional claims in published maps and institutional affiliations.

Copyright: (C) 2022 by the authors. Licensee MDPI, Basel, Switzerland. This article is an open access article distributed under the terms and conditions of the Creative Commons Attribution (CC BY) license (https:// creativecommons.org/licenses/by/ $4.0 /)$.
Third Department of Internal Medicine, Faculty of Medicine, University of Toyama, Toyama 930-0194, Japan; princess_and_pea_78@yahoo.co.jp (M.S.); m164.tym@gmail.com (H.M.); haruka52@med.u-toyama.ac.jp (H.F.); yasudaich@gmail.com (I.Y.)

* Correspondence: taando33@gmail.com; Tel.: +81-76-434-7300; Fax: +81-76-434-5027

\begin{abstract}
Chemotherapy-induced diarrhea (CID) is a common, severe side effect of chemotherapy, immunotherapy, and targeted therapy. Because patients are more prone to continuing chemotherapy if they do not suffer from CID, appropriate diagnosis and monitoring of this disease are essential. However, suitable monitoring methods are yet to be developed. To date, several studies have shown that small-bowel capsule endoscopy (SBCE) is useful in visualizing the entire small intestinal mucosa and detecting small intestinal abnormalities, including bleeding, malignant tumors, and mucosal injury, associated with the use of nonsteroidal anti-inflammatory drugs and low-dose aspirin. Currently, limited studies have evaluated the small intestinal mucosa using SBCE in patients receiving fluoropyrimidine-based chemotherapy or immune checkpoint inhibitors. These studies have reported that small intestinal mucosal injury is common in patients with severe fluoropyrimidine-induced diarrhea. SBCE might be a useful screening method for the early detection of enterocolitis induced by immune checkpoint inhibitors. SBCE may be a powerful tool for the diagnosis and monitoring of $\mathrm{CID}$, and understanding its indication, contraindication, and capsule-retention risk for each patient is important for clinicians.
\end{abstract}

Keywords: chemotherapy-induced diarrhea; fluoropyrimidine; capsule endoscopy; small intestinal mucosal injury; gastrointestinal cancer

\section{Introduction}

Most patients with cancer receive curative or palliative chemotherapeutic intervention throughout their treatment course. Gastrointestinal toxicities, including nausea, vomiting, ulceration, bleeding, constipation, and diarrhea, are often the major causes of treatment delays, dose adjustment, and treatment discontinuation during chemotherapy. Chemotherapy-induced diarrhea (CID) is one of the most common side effects of cancer therapy. Severe diarrhea is a life-threatening condition associated with dehydration and sepsis [1]. The drugs that are most frequently associated with diarrhea are 5-fluorouracil (5-FU) and irinotecan; the mechanisms underlying the action of these drugs are the inhibition of thymidylate synthase and topoisomerase I, respectively [2]. In addition, epidermal growth factor (EGF) receptors (EGFRs) and EGFR tyrosine kinase inhibitors (TKIs) are known to induce excess chloride secretion, which, in turn, causes secretory diarrhea $[3,4]$. Moreover, immune checkpoint inhibitors (ICIs) can induce colitis-associated diarrhea, which is endoscopically similar to ulcerative colitis [5,6]. Therefore, appropriate diagnosis and monitoring of diarrhea during chemotherapy are important, considering the fact that the absence of diarrhea would allow patients to continue chemotherapy, which would lead to a better disease prognosis. However, small intestinal mucosal findings have not been clarified in patients with CID because appropriate surveillance methods have not been developed yet.

Recently, small-bowel capsule endoscopy (SBCE) has been reported to play a pivotal role in the diagnosis of small-bowel disorders and, thus, has been widely used because 
of its noninvasive nature [7]. To date, several studies have shown that SBCE can be used to visualize the entire small intestinal mucosa and detect abnormalities, including bleeding, malignant tumors, and mucosal injury, associated with the use of nonsteroidal anti-inflammatory drugs (NSAIDs) and low-dose aspirin [8-10]. These studies have shown a possible use of SBCE for the evaluation of small-intestinal abnormalities in patients with CID. Therefore, this review sought to summarize the current state of literature on CID, with a focus on gastrointestinal cancer and the future possibility of using SBCE for the diagnosis and monitoring of CID.

\section{Initial Assessment of CID}

When diarrhea occurs during chemotherapy, its severity is primarily evaluated according to the Common Terminology Criteria for Adverse Events (CTCAE) (Table 1) [11].

Table 1. Common Terminology Criteria for Adverse Events for diarrhea (version 5.0), adapted from the National Cancer Institute.

\begin{tabular}{|c|c|c|c|c|c|}
\hline & \multicolumn{5}{|c|}{ Grade } \\
\hline & 1 & 2 & 3 & 4 & 5 \\
\hline Diarrhea & $\begin{array}{c}\text { Increase of }<4 \text { stools } \\
\text { per day over } \\
\text { baseline; mild } \\
\text { increase in ostomy } \\
\text { output compared to } \\
\text { baseline }\end{array}$ & $\begin{array}{l}\text { Increase of } 4-6 \text { stools } \\
\text { per day over baseline; } \\
\text { moderate increase in } \\
\text { ostomy output } \\
\text { compared to baseline; } \\
\text { and limiting } \\
\text { instrumental ADL }\end{array}$ & $\begin{array}{l}\text { Increase of } \geq 7 \text { stools } \\
\text { per day over baseline; } \\
\text { hospitalization } \\
\text { indicated; severe } \\
\text { increase in ostomy } \\
\text { output compared to } \\
\text { baseline; and limiting } \\
\text { self-care ADL }\end{array}$ & $\begin{array}{l}\text { Life-threatening } \\
\text { consequences: } \\
\text { urgent intervention } \\
\text { indicated }\end{array}$ & Death \\
\hline
\end{tabular}

ADL, activities of daily living.

From the perspective of CID management, the patient's general condition should be classified as either "complicated" or "uncomplicated" because this categorization can help determine the most appropriate course of action $[12,13]$. Complicated diarrhea is defined according to the American Society of Clinical Oncology guidelines, which is as follows: CTCAE grade 3 or 4 diarrhea or grade 1 or 2 diarrhea with one or more additional signs or symptoms, including cramping, nausea/vomiting (grade $\geq 2$ ), decreased performance status, fever, sepsis, neutropenia, frank bleeding, and dehydration. Uncomplicated diarrhea is defined as grade 1 or 2 diarrhea with no complicating symptoms. Intravenous fluid and antibiotics should be administered until all symptoms have resolved. Moreover, clinicians perform stool cultures (for Clostridium difficile, Escherichia coli, and other infectious organisms that may cause colitis), complete blood count, electrolyte panel test, and computed tomography (CT) to exclude infectious diarrhea and neutropenic enterocolitis [14]. Neutropenic enterocolitis is one of the most crucial differential diagnoses; this condition is associated with a neutrophil count of $<500 / \mathrm{L}$, fever, abdominal pain, and bowel-wall thickening [15]. The primary elements of disease onset appear to be intestinal mucosal injury combined with neutropenia and the immunocompromised state of the affected patients. These initial conditions often lead to intestinal edema, engorged vessels, and a disrupted mucosal surface, which make patients more vulnerable to bacterial intramural invasion. Therefore, its pathogenesis appears to overlap with that of CID, although the pathogenic mechanism is yet to be completely understood.

\section{Agents Associated with Diarrhea in Gastrointestinal Cancer}

Several clinical trials for each site of malignancy have clarified the frequency of diarrhea in patients receiving systemic chemotherapy. The proportions of patients suffering from diarrhea in recent, important clinical trials, which were based on the guidelines of National Comprehensive Cancer Network, focusing on systemic chemotherapy for gastrointestinal malignancy, are listed in Table 2 . The drugs most frequently associated 
with diarrhea are fluoropyrimidine and irinotecan. Recently, targeted therapy and ICIs have been reported to induce severe diarrhea.

Table 2. Pivotal clinical trial data of frequency of diarrhea in systemic chemotherapy for gastrointestinal malignancy.

\begin{tabular}{|c|c|c|c|c|c|c|}
\hline \multirow{2}{*}{$\begin{array}{c}\text { Type of } \\
\text { Malignancy }\end{array}$} & & \multicolumn{2}{|c|}{ Trial } & \multirow[b]{2}{*}{ Regimens } & \multicolumn{2}{|c|}{$\begin{array}{l}\text { Proportion with } \\
\text { Diarrhea }\end{array}$} \\
\hline & & Phase & Line & & $\begin{array}{c}\text { Any } \\
\text { Grade } \\
(\%)\end{array}$ & $\begin{array}{c}\text { Grade 3-4 } \\
(\%)\end{array}$ \\
\hline \multirow[t]{6}{*}{ Esophagus } & Sun et al. [16] & III & 1 st & $\begin{array}{c}\text { Fluoropyrimidine, cisplatin, and } \\
\text { pembrolizumab ** }\end{array}$ & 26 & 3 \\
\hline & & & & Fluoropyrimidine, cisplatin & 23 & 2 \\
\hline & Kato et al. [17] & III & Subsequent & Nivolumab ${ }^{* *}$ & 11 & 1 \\
\hline & & & & Paclitaxel or Docetaxel & 10 & 1 \\
\hline & Kojima et al. [18] & III & Subsequent & Pembrolizumab ** & 5.4 & 0.6 \\
\hline & & & & Paclitaxel, Docetaxel, or Irinotecan & 20.3 & 3.0 \\
\hline \multirow[t]{12}{*}{ Stomach } & Bang et al. [19] & III & 1st & $\begin{array}{l}\text { Fluoropyrimidine, cisplatin, and } \\
\text { trastuzumab * }\end{array}$ & 37 & 9 \\
\hline & & & & Fluoropyrimidine, cisplatin & 28 & 4 \\
\hline & Janjigian et al. [20] & III & 1st & $\begin{array}{l}\text { Fluoropyrimidine, oxaliplatin, and } \\
\text { nivolumab ** }\end{array}$ & 33 & 5 \\
\hline & & & & Fluoropyrimidine, oxaliplatin & 28 & 4 \\
\hline & Wilke et al. [21] & III & Subsequent & Paclitaxel, ramucirumab * & 33 & 4 \\
\hline & & & & Paclitaxel & 24 & 2 \\
\hline & Hironaka et al. [22] & III & Subsequent & Irinotecan & 44.5 & 4.5 \\
\hline & & & & Paclitaxel & 19.4 & 0.9 \\
\hline & Shitara et al. [23] & II & Subsequent & Trastuzumab deruxtecan & 32 & 2 \\
\hline & & & & Irinotecan or Paclitaxel & 32 & 2 \\
\hline & Shitara et al. [24] & III & Subsequent & Trifluridine and tipiracil & 23 & 3 \\
\hline & Kang et al. [25] & III & Subsequent & Nivolumab** & 7 & 1 \\
\hline \multirow[t]{4}{*}{ GIST } & Demetri et al. [26] & III & $1 \mathrm{st}$ & Imatinib* & 44.9 & 2.0 \\
\hline & Demetri et al. [27] & III & Subsequent & Sunitinib* & 29 & 3 \\
\hline & Demetri et al. [28] & III & Subsequent & Regorafenib* & 45 & 5 \\
\hline & Bauer et al. [29] & III & Subsequent & Ripretinib * & 28.2 & NA \\
\hline \multirow[t]{4}{*}{ Neuroendocrine } & Yao et al. [30] & III & $\begin{array}{c}\text { 1st, } \\
\text { Subsequent }\end{array}$ & Everolimus* & 34,31 & 3,7 \\
\hline & Raymond [31] & III & Subsequent & Sunitinib * & 59 & 5 \\
\hline & Rinke [32] & III & 1st & Octreotide & 14.3 & NA \\
\hline & Caplin [33] & III & 1st & Lanreotide & 26 & NA \\
\hline \multirow{7}{*}{$\begin{array}{l}\text { Hepatocellular } \\
\text { carcinoma }\end{array}$} & Finn [34] & III & 1st & Atezolizumab ${ }^{* *}$, bevacizumab * & 18.8 & 1.8 \\
\hline & & & & Sorafenib * & 49.4 & 5.1 \\
\hline & $\begin{array}{c}\text { Llovet [35], Cheng } \\
\text { [36] }\end{array}$ & III & 1st & Sorafenib * & $39,25.5$ & $8,6.0$ \\
\hline & Kudo [37] & III & 1 st & $\begin{array}{l}\text { Lenvatinib * } \\
\text { Sorafenib * }\end{array}$ & $\begin{array}{l}39 \\
46\end{array}$ & $\begin{array}{l}4 \\
4\end{array}$ \\
\hline & Bruix [38] & III & Subsequent & Regorafenib* & 41 & 3 \\
\hline & Abou-Alfa [39] & III & Subsequent & Cabozantinib* & 54 & 11 \\
\hline & Zhu [40] & III & Subsequent & Ramucirumab * & 16 & 0 \\
\hline \multirow{5}{*}{$\begin{array}{l}\text { Biliary tract } \\
\text { cancer }\end{array}$} & Valle [41] & III & 1 st & Gemcitabine, Cisplatin & NA & NA \\
\hline & & & & Gemcitabine & NA & NA \\
\hline & Morizane [42] & III & 1 st & Gemcitabine, Cisplatin & 13.5 & 1.2 \\
\hline & & & & Gemcitabine, S-1 & 20.9 & 1.1 \\
\hline & Abou [43] & II & Subsequent & Pemigatinib * & 37 & 3 \\
\hline \multirow{2}{*}{$\begin{array}{l}\text { Pancreatic } \\
\text { cancer }\end{array}$} & Conroy [44] & III & $\begin{array}{l}1 \mathrm{st}, \\
\text { adjuvant }\end{array}$ & FOLFIRINOX & $12.7,84.4$ & NA, 19.9 \\
\hline & & & & Gemcitabine & $1.8,49.0$ & NA, 3.7 \\
\hline
\end{tabular}


Table 2. Cont.

\begin{tabular}{|c|c|c|c|c|c|c|}
\hline \multirow{2}{*}{$\begin{array}{c}\text { Type of } \\
\text { Malignancy }\end{array}$} & & \multicolumn{2}{|c|}{ Trial } & \multirow[b]{2}{*}{ Regimens } & \multicolumn{2}{|c|}{$\begin{array}{l}\text { Proportion with } \\
\text { Diarrhea }\end{array}$} \\
\hline & & Phase & Line & & $\begin{array}{c}\text { Any } \\
\text { Grade } \\
(\%)\end{array}$ & $\begin{array}{c}\text { Grade 3-4 } \\
\text { (\%) }\end{array}$ \\
\hline \multirow{34}{*}{$\begin{array}{l}\text { Colorectal } \\
\text { cancer }\end{array}$} & Von Hoff [45] & III & 1 st & $\begin{array}{l}\text { Gemcitabine, albumin-bound } \\
\text { paclitaxel }\end{array}$ & NA & 6 \\
\hline & & & & Gemcitabine & NA & 1 \\
\hline & Moore [46] & III & 1 st & Gemcitabine, erlotinib * & 56 & 6 \\
\hline & & & & Gemcitabine & 41 & 2 \\
\hline & Talia [47] & & $\begin{array}{l}\text { 1st mainte- } \\
\text { nance }\end{array}$ & Olaparib * & 29 & 0 \\
\hline & Wang [48] & III & Subsequent & $\begin{array}{l}\text { 5-FU, leucovorin, liposomal } \\
\text { irinotecan }\end{array}$ & 59 & 13 \\
\hline & & & & liposomal irinotecan & 70 & 21 \\
\hline & & & & 5-FU, leucovorin & 26 & 4 \\
\hline & de Gramont [49] & III & $1 \mathrm{st}$ & FOLFOX & 43.8 & 5.3 \\
\hline & & & & 5-FU, Leucovorin & 58.8 & 11.9 \\
\hline & Douillard [50] & III & $1 \mathrm{st}$ & FOLFOX, panitumumab * & NA & 18.9 \\
\hline & & & & FOLFOX & NA & 9.1 \\
\hline & Heinemann [51] & III & 1 st & FOLFIRI, bevacizumab * & 57 & 11 \\
\hline & & & & FOLFIRI & 52 & 13 \\
\hline & Cremolini [52] & III & 1 st & FOLFOXIRI, bevacizumab* & NA & 18.8 \\
\hline & & & & FOLFIIR, bevacizumab * & NA & 10.6 \\
\hline & Cunningham [53] & III & 1 st & Capecitabine, bevacizumab * & 40 & 7 \\
\hline & & & & Capecitabine & 35 & 6 \\
\hline & Andre [54] & III & $1 \mathrm{st}$ & Pembrolizumab ** & 44 & 6 \\
\hline & & & & Chemotherapy & 62 & 11 \\
\hline & Peeters [55] & III & Subsequent & FOLFIRI, panitumumab * & NA & 18.5 \\
\hline & & & & FOLFIRI & NA & 9.8 \\
\hline & Tabernero [56] & III & Subsequent & FOLFIRI, ramucirumab * & 60 & 11 \\
\hline & & & & FOLFIRI & 51 & 9 \\
\hline & Van Cutsem [57] & III & Subsequent & FOLFIRI, ziv-aflibercept * & 69.2 & 19.3 \\
\hline & & & & FOLFIRI & 56.5 & 7.8 \\
\hline & Overman [58] & II & Subsequent & Nivolumab ${ }^{* *}$, Ipilimumab ${ }^{* *}$ & 22 & 2 \\
\hline & Kopetz [59] & III & Subsequent & $\begin{array}{l}\text { Encrafenib *, binimetinib *, and } \\
\text { cetuximab * }\end{array}$ & 62 & 10 \\
\hline & & & & Enforafenib ${ }^{*}$, cetuximab * & 33 & 2 \\
\hline & & & & FOLFIRI/Irinotecan, Cetuximab * & 48 & 10 \\
\hline & Cunningham [60] & III & Subsequent & Irinotecan, Cetuximab * & NA & 21.2 \\
\hline & & & & Irinotecan & NA & 1.7 \\
\hline & Mayer [61] & III & Subsequent & Trifluridine + tipiracil & 32 & 3 \\
\hline & Grothey [62] & III & Subsequent & Regorafenib * & 34 & 7 \\
\hline \multicolumn{7}{|l|}{ Solid tumors } \\
\hline \multirow[t]{2}{*}{ NTRK fusion } & Drion [63] & $\mathrm{I} / \mathrm{II}$ & Subsequent & Larotectinib * & 30 & 2 \\
\hline & Doebele [64] & $\mathrm{I} / \mathrm{II}$ & Subsequent & Entrectinib * & 21 & 1 \\
\hline $\begin{array}{c}\text { MSI-high } \\
\text { (noncolorectal) }\end{array}$ & Marabelle [65] & II & Subsequent & Pembrolizumab ** & 12 & 0 \\
\hline
\end{tabular}

FOLFOXIRI, oxaliplatin, irinotecan, fluorouracil, and folinic acid (leucovorin); FOLFIRI, folinic acid (leucovorin), fluorouracil, and irinotecan; FOLFOX, oxaliplatin, fluorouracil, and folinic acid (leucovorin); NTRK, neurotrophic tyrosine receptor kinase; MSI, microsatellite instability; ${ }^{*}$ targeted therapy; and ${ }^{* *}$ immune checkpoint inhibitor. GIST, gastrointestinal stromal tumor.

\subsection{Fluoropyrimidine}

The thymidylate synthetase inhibitor 5-FU interrupts DNA synthesis, which then leads to cell death by apoptosis. 5-FU is the primary agent used in systemic chemotherapy, particularly for gastrointestinal cancer, and its prodrugs such as capecitabine, S-1, 
and oral tegafur/uracil are known to induce similar effects and exhibit a similar toxicity profile [66-68].

The risk of diarrhea increases with the addition of leucovorin [69]. This is particularly evident in a combination therapy comprising intravenous 5-FU and irinotecan as both of these drugs are known to exert direct toxic effects on the intestinal mucosa. In trials with weekly bolus containing 5 -FU and leucovorin for colorectal cancer, $15 \%$ patients suffered from grade 3 or 4 diarrhea [70]. Similarly, oxaliplatin combined with intravenous 5-FU has shown increased rates of gastrointestinal toxicity [71]. In addition, genetics might also contribute to drug-specific toxic effects as a previous study demonstrated that dihydropyrimidine dehydrogenase $(D P Y D)$ deficiency was associated with reduced clearance of and prolonged exposure to fluoropyrimidines. The most common genetic mutation observed in DPYD is an exon 14 skip mutation, which is a G-to-A change in the $5^{\prime}$ splicing recognition site of intron 14; this mutation is observed in $1-2 \%$ of the population [72]. Homozygous mutations in DPYD are considered scarce and occur in 1 per 5000-10,000 patients; however, these mutations are associated with rapid and severe myelosuppression, skin toxicity, mucositis, and diarrhea [72].

The pathophysiology of fluoropyrimidine-induced diarrhea is not fully understood, although earlier studies have reported that 5-FU induces the loss of crypt and villous cellularity through apoptosis and the inhibition of cell cycle progression [73]. The involvement of inflammatory mediators in the pathogenesis of intestinal mucositis and diarrhea was investigated in several studies [74]. Tumor necrosis factor-alpha and interleukin-1beta expression has been found to be highly elevated in 5-FU-treated mice [75]. In addition, $\mathrm{NF}-\mathrm{kB}$, which is a central coordinator of the innate and adaptive immune responses, is activated in the small intestinal mucosa 2 days after 5-FU administration [76]. Other studies have also demonstrated the involvement of nicotinamide-adenine-dinucleotide-phosphateoxidase-dependent reactive oxygen species generation in phagocytes. In a previous study, $\mathrm{CT}$ revealed the increased wall thickness of the small intestine, and ileal biopsy with colonoscopy in patients with 5-FU-induced diarrhea revealed markedly acute and chronic inflammation [77].

\subsection{Irinotecan}

Irinotecan is a semisynthetic prodrug analog of camptothecin, and its anticancer effect is based on the inhibition of nuclear topoisomerase I [78]. Irinotecan is enzymatically converted by de-esterification into its active metabolite $\mathrm{SN}-38$, which forms a cleavable complex by binding to topoisomerase I [79]. Currently, irinotecan is widely used in combination other regimens for the treatment of advanced colorectal and pancreatic cancers.

Irinotecan induces early- or delayed-onset diarrhea, which is defined as diarrhea that occurs $>24 \mathrm{~h}$ after irinotecan administration. These phases result from different pathological mechanisms. Early-onset diarrhea is caused by the acute cholinergic properties of irinotecan and is often accompanied by other symptoms of cholinergic excess, such as abdominal cramping, rhinitis, lacrimation, and salivation. This toxicity is easily controlled with atropine. Conversely, SN-38 induces irreversible DNA damage in cancer cells, and its accumulation in the intestinal mucosa is believed to be responsible for enterotoxicity in delayed-onset diarrhea. The risk of grade 3 or 4 diarrhea during irinotecan treatment is increased in patients with Gilbert's syndrome, which is characterized by decreased bilirubin glucuronidation. Therefore, homozygosity for UGT1A1* 28 and * 6 alleles leads to decreased UGT1A1 expression or activation, increased myelosuppression, and severe diarrhea risks [80-82].

The pathophysiology of delayed-onset diarrhea is associated with the following three mechanisms: (1) direct damage to the intestinal epithelium, (2) infiltration of inflammatory cells that release immunogenic mediators, and (3) bacterial dysbiosis. Studies using rodent models have suggested that SN-38 is transformed into SN-38 glucuronide (SN-38G) by glucuronyltransferase in the liver; the latter is a much less toxic metabolite that is excreted into the gastrointestinal tract via bile. In stool, however, SN-38G can be hydrolyzed by 
$\beta$-glucuronidases of the gastrointestinal bacteria, and it then reverts into the SN-38 form and causes damage to the mucosa during drug excretion; however, this mechanism has not been confirmed in humans $[83,84]$.

\subsection{Targeted Therapy}

The EGF and vascular endothelial growth factor (VEGF) pathways are crucial for tumor cell proliferation, angiogenesis invasion, and metastasis $[85,86]$. Therefore, the inhibition of these pathways with anti-EGFR antibodies, EGFR TKIs, VEGF antibodies, and multikinase inhibitors such as those against VEGF receptors (VEGFRs) is an effective strategy that targets the molecular basis of gastrointestinal malignancies $[87,88]$. In patients receiving TKIs, diarrhea might occur as early as 2-3 days after treatment administration, and its occurrence is up to $60 \%$ for all grades [89]. Grade 3 diarrhea develops in approximately 6-9\% of patients, which results in dose reduction. Conversely, in patients receiving monoclonal antibodies, including cetuximab and panitumumab, grade 2 diarrhea is observed in up to $21 \%$ of patients, whereas grade 3 diarrhea is observed in approximately 1-2\% [90-92].

The pathophysiology of targeted-therapy-associated diarrhea may be associated with excess chloride secretion because of dysregulated EGFR or VEGFR signaling, which might cause secretory diarrhea [4]. Moreover, EGFR pathway inhibition might prevent epithelial repair when combined with chemotherapy-induced local irritation due to fecal metabolites as well as transient lactose intolerance [93]. In addition, the inhibition of VEGFR signaling might lead to direct ischemic mucosal damage via the dysregulation of microcirculation in the gastrointestinal tract. Furthermore, multiple areas of colonic ulceration with perforation have been reported during treatment with multikinase inhibitors [94,95].

\subsection{ICIs}

ICIs are novel anticancer drugs whose mechanism of action depends on their interaction with the immune system. Their targets are molecules such as cytotoxic T-lymphocyteassociated protein 4 (CTLA-4), as well as programmed cell death protein 1 (PD-1) and its ligand PD-L1, which are expressed on the surface of T-lymphocytes. The adverse effects of ICIs relate to the suppression of T-cell activation. A recent systematic review and meta-analysis reported that the overall incidence rates of gastrointestinal toxicities in patients receiving anti-PD-1/PD-L1 monotherapy, ipilimumab monotherapy, and combination therapy were $1.3 \%, 9.1 \%$, and $13.6 \%$, respectively, for all grades of colitis; $0.9 \%, 6.8 \%$, and $9.4 \%$, respectively, for grade 3 or 4 colitis; and $1.2 \%, 7.9 \%$, and $9.2 \%$, respectively, for grade 3 or 4 diarrhea [96]. The predominant symptom in ICI-associated colitis is diarrhea with variable onset that depends on each treatment regimen. The median time to onset in patients receiving anti-CTLA-4 therapy is 5 weeks [97-100], whereas it is 2-4 months in patients receiving anti-PD-1 therapy [101,102]. Occasionally, ICI-associated colitis can occur even after 2 years [103].

Studies on endoscopic intervention for ICI-associated colitis have reported colonoscopic findings such as erythema, vascular pattern loss, mucosal or luminal hemorrhage, erosions, and ulcers [104]. Recently, ICI-associated colitis has been differentiated into five types based on endoscopic and histological findings; these types are as follows [104]: (1) focal active colitis, occasional foci of acute inflammation in the absence of chronic inflammation or significant crypt injury; (2) lymphocytic colitis, increase in the number of intraepithelial and lamina propria lymphocytes in the absence of crypt architectural distortion; (3) collagenous colitis, increases in the thickness of the subepithelial collagen plate and number of lymphocytes in the lamina propria in the absence of crypt architectural distortion; (4) UC-like, active chronic inflammation with goblet cell depletion and crypt architectural distortion; and (5) NSAIDs/infection-like, predominantly acute, superficial inflammation with the attenuation of crypt and/or surface epithelium.

Several guidelines have been developed to aid decision-making in the cases of patients suspected with ICI-associated colitis, and most guidelines are based on the CTCAE diarrhea grade [5,105-107]. All guidelines recommend the discontinuation of ICIs and 
early initiation of corticosteroids according to the diarrhea grade since the primary goals of these treatments are to promptly improve symptoms; avoid complications; and, wherever suitable, ultimately allow the continued use of ICIs to improve patient survival.

\section{Endoscopic Approach for CID}

To date, limited studies have examined endoscopic findings of the small intestine in patients with CID, although diarrhea or mucositis is frequently observed during chemotherapy administration. In 1999, mucosal damage of the terminal ileum diagnosed through colonoscopy was reported in six patients with colon cancer who had been receiving 5-FUbased chemotherapy [108,109]. Since then, several studies, including case reports and series, have reported similar findings in patients with fluoropyrimidine-induced diarrhea [110]. However, the extent and severity of this damage are yet to be investigated in detail given that a considerable portion of the small intestine is beyond the reach of a colonoscope. Recently, mucosal lesions in the entire small intestine have been revealed using SBCE for CID [111-113].

\subsection{Current Status of SBCE and Its Possible Indication for CID}

$\mathrm{SBCE}$ is a routine, first-line investigational tool for many small-bowel pathologies, and five platforms of SBCE have been approved and are available for use worldwide [7]. The size and weight of one of the platforms, the PillCam ${ }^{\mathrm{TM}}$ SB3 video capsule endoscope, are $26.2 \times 11.2 \mathrm{~mm}$ and $3.00 \mathrm{~g}$, respectively. Its battery ensures $11 \mathrm{~h}$ of work time, during which the capsule obtains 2-6 images if it is accelerated via peristalsis, after which the pictures are transmitted to the portable data recorder (Figure 1).

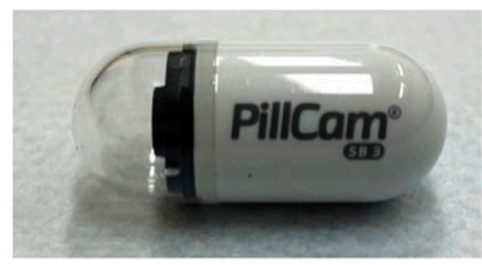

A

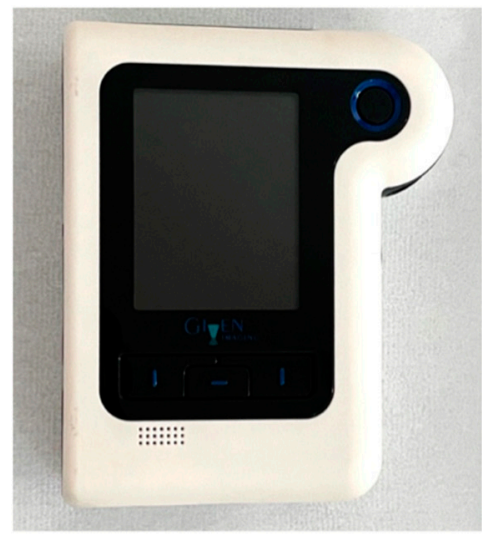

B

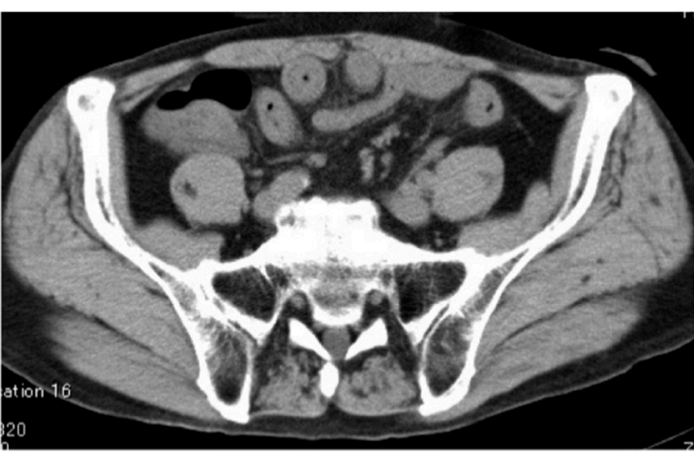

C

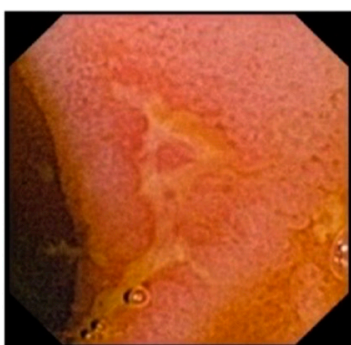

$\mathrm{D}$

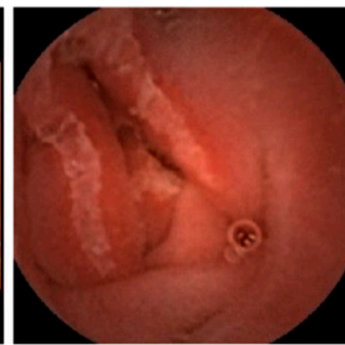

E

Figure 1. Images of capsule endoscopy of small intestinal mucosal injuries. The system of capsule endoscopy for CID contains the following elements: the capsule (A) and data recorder (B). SBCE imaging data were analyzed using reading software. CT scan suggested wall thickness of small intestine (C), and capsule endoscopy revealed small intestinal mucosal injuries with redness (D) and ulcers (E) in patient with CID.

The primary indications for the use of SBCE include the following: (1) occult gastrointestinal bleeding, (2) suspected Crohn's disease, (3) suspected small-bowel tumor, (4) surveillance for inherited polyposis syndromes, (5) evaluation of any abnormal smallbowel imaging, (6) evaluation of partially responsive celiac disease, and (7) evaluation 
of drug-induced small-bowel injury and response to medications. Specifically, SBCE can be used to monitor the deleterious effects of drugs. This modality clearly demonstrates NSAID-induced small-bowel damage such as erythema, erosions, small ulcerations, and web-like strictures [8]. Moreover, its utility has been reported during the monitoring of small intestinal mucosa in patients receiving transplants and mucosal healing of the small bowel in patients with Crohn's disease after medical treatments [114]. However, some contraindications include (1) major abdominal surgery performed $>6$ months ago (relative), (2) presence of swallowing disorder, (3) noncompliance, (4) previous history/suspected small-bowel obstruction, and (5) pregnancy. Moreover, capsule retention, which is a major complication of SBCE, occurs in up to $20 \%$ of cases when it is performed in patients with suspected bowel obstruction [7]. Once retention is diagnosed, endoscopic (balloon-assisted enteroscopy) or surgical removal is deemed necessary. The use of the Agile ${ }^{\mathrm{TM}}$ Patency Capsule (Given Imaging, Yokneam, Israel) can reduce the retention rate when pretest suspected retention is high, and a conventional capsule can be safely used once the patency capsule is excreted undamaged.

Therefore, when SBCE is considered during chemotherapy, clinicians should confirm that patients satisfy the following proposed criteria: the (1) absence of any massive ascites or severe peritoneal dissemination, (2) ability to continue chemotherapy, and (3) capability of oral intake. Furthermore, depending on each patient's condition, a patency capsule should be used to confirm intestinal patency based on the operator's discretion.

\subsection{Backglound Literature and SBCE Findings in Patients with CID}

The following databases were searched by two authors (TA and MS): PubMed (1966October 2021) and MEDLINE (1946-October 2021). Databases were searched using combinations of the following keywords: "diarrhea", "capsule endoscopy", and "cancer."

All articles, irrespective of publication date, were considered. Studies were excluded if the (1) full text was unavailable, (2) article was not written in English, and (3) article did not mention both diarrhea and capsule endoscopy. After applying the search strategy and filtering the 44 articles obtained, four full-length articles that included discussions on capsule endoscopy in CID were identified and read by two authors. The study findings were extracted from the articles reviewed; Table 3 summarizes these findings. In these reports, primary sites of 38 patients were non-gastrointestinal, including lung, breast, ovarian, melanoma, and kidney cancers, although the sites of large population were gastrointestinal.

Table 3. Summary of SBCE studies in patients receiving anticancer therapy.

\begin{tabular}{|c|c|c|c|c|}
\hline & Ota [115] & Sakumura [77] & Shimozaki [116] & Dore [113] \\
\hline Study Design & Retrospective & Retrospective & Prospective & Retrospective \\
\hline Objective & $\begin{array}{l}\text { Work-Up } \\
\text { for CID }\end{array}$ & $\begin{array}{l}\text { Work-Up } \\
\text { for CID }\end{array}$ & $\begin{array}{l}\text { Screening } \\
\text { for ICI }\end{array}$ & $\begin{array}{l}\text { Screening for } \\
\text { Chemotherapy }\end{array}$ \\
\hline $\begin{array}{l}\text { Number of patients who underwent SBCE } \\
\text { Primary malignancy }\end{array}$ & 16 & 13 & 23 & 20 \\
\hline $\begin{array}{c}\text { Gastrointestinal/Non-gastrointestinal } \\
\text { Anticancer drug }\end{array}$ & $10 / 6$ & $13 / 0$ & $8 / 15$ & $3 / 17$ \\
\hline Fluoropyrimidine: 5-FU/S-1/Capecitabine & $16(12 / 2 / 2)$ & $13(2 / 7 / 4)$ & 0 & $11(11 / 0 / 0)$ \\
\hline $\begin{array}{c}\text { Molecular targeted therapy } \\
\text { ICIs: }\end{array}$ & 3 & 4 & 0 & 3 \\
\hline $\begin{array}{c}\text { Nivolumab/Pembrolizumab/Nivolumab + } \\
\text { Ipilimumab }\end{array}$ & 0 & 0 & $23(20 / 2 / 1)$ & 0 \\
\hline Number of patients with CID & 10 & 13 & 2 & 0 \\
\hline $\begin{array}{l}\text { Diarrhea grade: } 0 / 1 / 2 / 3 \\
\text { Findings of SBCE }\end{array}$ & $6 / 7 / 3 / 0$ & $0 / 3 / 4 / 6$ & $0 / 0 / 1 / 1$ & $\mathrm{~N} / \mathrm{A}$ \\
\hline Edema or Redness: Negative/Positive & $\mathrm{N} / \mathrm{A}$ & $11 / 2$ & $1 / 22$ & $\mathrm{~N} / \mathrm{A}$ \\
\hline Mucosal brake: Negative/Positive & $8 / 8$ & $5 / 8$ & $5 / 23$ & $5 / 15$ \\
\hline Adverse events of SBCE & 0 & 0 & 0 & 0 \\
\hline
\end{tabular}

SBCE, small-bowel-capsule endoscopy; 5-FU, 5-fluorouracil; ICIs, immune checkpoint inhibitors; CID chemotherapy-induced diarrhea; CTCAE, common terminology criteria for adverse events; and N/A, not available. 
To date, two studies have evaluated the small intestinal mucosa using SBCE in patients receiving 5-FU-, S-1-, and capecitabine-based chemotherapy. Ota et al. performed SBCE in 16 patients with or without diarrhea and reported that the grade of diarrhea significantly correlated with the percentage of patients with a small intestinal mucosal break, which was defined as a mucosal defect (grade $0,16.7 \%$; grade 1, 57.1\%; and grade 2, 100\%; $p=0.016$ ) [115]. Moreover, they quantified the number of mucosal injuries, and the number of mucosal breaks was 6.5 (range: 1-20) and 0 (range: $0-13$ ) in the oral fluoropyrimidine and 5-FU groups, respectively. Sakumura et al. surveyed 536 patients with advanced or recurrent gastrointestinal cancer who received fluoropyrimidine-based chemotherapy [77]. Among the patients, $32(6 \%)$ had developed complicated CID, with symptoms such as cramping, vomiting, fever, and sepsis. SBCE was performed in 13 patients with complicated CID, and small intestinal mucosal breaks developed in 8 (61.5\%) patients. These findings suggested that mucosal injuries of the small intestine are common in patients with severe fluoropyrimidine-induced diarrhea and that oral fluoropyrimidine intake is an independent risk factor. Recently, to screen for CID, Shimozaki et al. prospectively evaluated the entire small intestine and colon using SBCE in 23 patients receiving ICIs [116]. Six patients (26.1\%) exhibited edematous or mucosal breaks within 8 weeks after the administration of ICIs, although they did not develop colitis. This indicates that SBCE is a useful screening tool for the early detection of ICI-induced enterocolitis. No adverse events associated with SBCE, including capsule retention, were observed in any study.

\section{Potential Utility of SBCE for CID Monitoring}

Recent findings regarding SBCE do not mandate the use of this tool for the diagnosis of CID in all such patients. We believe that SBCE should be performed in patients with suspected or confirmed diagnosis of pre-existing small-bowel disease or in those who do not recover from diarrhea after stopping chemotherapy. However, the high frequency of mucosal injury in severe CID might influence the treatment strategy. For instance, clinicians may consider early administration of antibiotics for enterocolitis in febrile patients with CID, in addition to loperamide [117]. Sakumura et al. reported that of the 32 patients with complicated fluoropyrimidine-induced diarrhea, cramping, fever, and sepsis were observed in $15(60 \%), 8(32 \%), 6(24 \%)$, and $3(12 \%)$ patients, respectively [77]. This finding suggests that fluoropyrimidine-driven mucosal damage is associated with the disruption of intestinal homeostasis and induces bacterial translocation.

In ICI-associated enterocolitis, early evaluation via SBCE might be considered because it improves the clinical outcomes by identifying high-risk patients who might benefit from early administration of immunosuppressants. Patient mucosa appearing normal on endoscopic evaluation does not exclude the diagnosis of ICI-associated diarrhea, but such patients may have a superior prognosis to those with visible ulcerations [118]. Moreover, the resolution of clinical symptoms does not always reflect endoscopic remission after diarrhea treatment. Among patients receiving vedolizumab, $86 \%$ achieved clinical remission, whereas only 54\% achieved endoscopic remission [119]. Furthermore, the confirmation of endoscopic remission may be important for decision-making regarding the reintroduction of ICIs because it is associated with the recurrence of enterocolitis, particularly in the nonremission state $[100,101]$.

\section{Future Directions and Conclusions}

SBCE may be one of tools for understanding the cause of treatment-associated diarrhea and disease monitoring in patients with cancer with CID, although its indication should be limited considering its contraindication and capsule-retention risk. Further studies are warranted to confirm existing knowledge and bring us one step closer to improved clinical practices for CID.

Author Contributions: T.A. and M.S. devised the project and main conceptual ideas; H.M. and H.F. reviewed manuscript; and I.Y. supervised the concept and design and reviewed manuscript. All authors have read and agreed to the published version of the manuscript. 
Funding: This research received no external funding.

Institutional Review Board Statement: Not applicable.

Informed Consent Statement: Not applicable.

Data Availability Statement: Not applicable.

Conflicts of Interest: The authors declare no conflict of interest.

\section{References}

1. Gibson, R.J.; Bowen, J.M.; Inglis, M.R.; Cummins, A.G.; Keefe, D.M. Irinotecan causes severe small intestinal damage, as well as colonic damage, in the rat with implanted breast cancer. J. Gastroenterol. Hepatol. 2003, 9, 1095-1100. [CrossRef]

2. Conti, J.A.; Kemeny, N.E.; Saltz, L.B.; Huang, Y.; Tong, W.P.; Chou, T.C.; Sun, M.; Pulliam, S.; Gonzalez, C. Irinotecan is an active agent in untreated patients with metastatic colorectal cancer. J. Clin. Oncol. 1996, 14, 709-715. [CrossRef]

3. Li, J.; Gu, J. Risk of gastrointestinal events with newly approved (after 2011) vascular endothelial growth factor receptor tyrosine kinase inhibitors in cancer patients: A meta-analysis of randomized controlled trials. Eur. J. Clin. Pharmacol. 2017, 73, 1209-1217. [CrossRef]

4. Pessi, M.A.; Zilembo, N.; Haspinger, E.R.; Molino, L.; Di Cosimo, S.; Garassino, M.; Ripamonti, C.I. Targeted therapy-induced diarrhea: A review of the literature. Crit. Rev. Oncol. Hematol. 2014, 90, 165-179. [CrossRef]

5. Brahmer, J.R.; Lacchetti, C.; Schneider, B.J.; Atkins, M.B.; Brassil, K.J.; Caterino, J.M.; Chau, I.; Ernstoff, M.S.; Gardner, J.M.; Ginex, P.; et al. National Comprehensive Cancer Network. Management of immune-related adverse events in patients treated with immune checkpoint inhibitor therapy: American Society of Clinical Oncology clinical practice guideline. J. Clin. Oncol. 2018, 36, 1714-1768. [CrossRef]

6. Gong, Z.; Wang, Y. Immune checkpoint inhibitor-mediated diarrhea and colitis: A clinical review. JCO Oncol. Pract. 2020, 16, 453-461. [CrossRef]

7. Hosoe, N.; Takabayashi, K.; Ogata, H.; Kanai, T. Capsule endoscopy for small-intestinal disorders: Current status. Dig. Endosc. 2019, 31, 498-507. [CrossRef]

8. Maiden, L.; Thjodleifsson, B.; Theodors, A.; Gonzalez, J.; Bjarnason, I. A quantitative analysis of NSAID-induced small bowel pathology by capsule enteroscopy. Gastroenterology 2005, 128, 1172-1178. [CrossRef]

9. Endo, H.; Sakai, E.; Kato, T.; Umezawa, S.; Higurashi, T.; Ohkubo, H.; Nakajima, A. Small bowel injury in low-dose aspirin users. J. Gastroenterol. 2015, 50, 378-386. [CrossRef]

10. Fujimori, S.; Gudis, K.; Sakamoto, C. A review of anti-inflammatory drug-induced gastrointestinal injury: Focus on prevention of small intestinal injury. Pharmaceuticals 2010, 3, 1187-1201. [CrossRef]

11. Common Terminology Criteria for Adverse Events (CTCAE) Version 5.0. Available online: https://ctep.cancer.gov/ protocoldevelopment/electronic_applications/ctc.htm (accessed on 22 January 2022).

12. Benson, A.B., 3rd; Ajani, J.A.; Catalano, R.B.; Engelking, C.; Kornblau, S.M.; Martenson, J.A., Jr.; McCallum, R.; Mitchell, E.P.; O'Dorisio, T.M.; Vokes, E.E.; et al. Recommended guidelines for the treatment of cancer treatment-induced diarrhea [Guideline Practice Guideline Research Support, Non-U.S. Gov't]. J. Clin. Oncol. 2004, 22, 2918-2926. [CrossRef] [PubMed]

13. Andreyev, J.; Ross, P.; Donnellan, C.; Lennan, E.; Leonard, P.; Waters, C.; Wedlake, L.; Bridgewater, J.; Glynne-Jones, R.; Allum, W.; et al. Guidance on the management of diarrhoea during cancer chemotherapy. Lancet Oncol. 2014, 15, e447-e460. [CrossRef]

14. Gorschlüter, M.; Mey, U.; Strehl, J.; Ziske, C.; Schepke, M.; Schmidt-Wolf, I.G.; Sauerbruch, T.; Glasmacher, A. Neutropenic enterocolitis in adults: Systematic analysis of evidence quality. Eur. J. Haematol. 2005, 75, 1-13. [CrossRef] [PubMed]

15. Rodrigues, F.G.; Dasilva, G.; Wexner, S.D. Neutropenic enterocolitis. World J. Gastroenterol. 2017, 23, 42-47. [CrossRef] [PubMed]

16. Sun, J.M.; Shen, L.; Shah, M.A.; Enzinger, P.; Adenis, A.; Doi, T.; Kojima, T.; Metges, J.P.; Li, Z.; Kim, S.B.; et al. Pembrolizumab plus chemotherapy versus chemotherapy alone for first-line treatment of advanced oesophageal cancer (KEYNOTE-590): A randomised, placebo-controlled, phase 3 study. Lancet 2021, 398, 759-771. [CrossRef]

17. Kato, K.; Cho, B.C.; Takahashi, M.; Okada, M.; Lin, C.Y.; Chin, K.; Kadowaki, S.; Ahn, M.J.; Hamamoto, Y.; Doki, Y.; et al. Nivolumab versus chemotherapy in patients with advanced oesophageal squamous cell carcinoma refractory or intolerant to previous chemotherapy (ATTRACTION-3): A multicentre, randomised, open-label, phase 3 trial. Lancet Oncol. 2019, 20, 1506-1517. [CrossRef]

18. Kojima, T.; Shah, M.A.; Muro, K.; Francois, E.; Adenis, A.; Hsu, C.H.; Doi, T.; Moriwaki, T.; Kim, S.B.; Lee, S.H.; et al. Randomized Phase III KEYNOTE-181 study of pembrolizumab versus chemotherapy in advanced esophageal cancer. J. Clin. Oncol. 2020, 38, 4138-4148. [CrossRef]

19. Bang, Y.J.; Van Cutsem, E.; Feyereislova, A.; Chung, H.C.; Shen, L.; Sawaki, A.; Lordick, F.; Ohtsu, A.; Omuro, Y.; Satoh, T.; et al. Trastuzumab in combination with chemotherapy versus chemotherapy alone for treatment of HER2-positive advanced gastric or gastro-oesophageal junction cancer (ToGA): A phase 3, open-label, randomised controlled trial. Lancet 2010, 376, 687-697. [CrossRef] 
20. Janjigian, Y.Y.; Shitara, K.; Moehler, M.; Garrido, M.; Salman, P.; Shen, L.; Wyrwicz, L.; Yamaguchi, K.; Skoczylas, T.; Campos Bragagnoli, A.; et al. First-line nivolumab plus chemotherapy versus chemotherapy alone for advanced gastric, gastro-oesophageal junction, and oesophageal adenocarcinoma (CheckMate 649): A randomised, open-label, phase 3 trial. Lancet 2021, 398, 27-40. [CrossRef]

21. Wilke, H.; Muro, K.; Van Cutsem, E.; Oh, S.C.; Bodoky, G.; Shimada, Y.; Hironaka, S.; Sugimoto, N.; Lipatov, O.; Kim, T.Y.; et al. Ramucirumab plus paclitaxel versus placebo plus paclitaxel in patients with previously treated advanced gastric or gastro-oesophageal junction adenocarcinoma (Rainbow): A double-blind, randomised phase 3 trial. Lancet Oncol. 2014, 15, 1224-1235. [CrossRef]

22. Hironaka, S.; Ueda, S.; Yasui, H.; Nishina, T.; Tsuda, M.; Tsumura, T.; Sugimoto, N.; Shimodaira, H.; Tokunaga, S.; Moriwaki, T.; et al. Randomized, open-label, phase III study comparing irinotecan with paclitaxel in patients with advanced gastric cancer without severe peritoneal metastasis after failure of prior combination chemotherapy using fluoropyrimidine plus platinum: WJOG 4007 trial. J. Clin. Oncol. 2013, 31, 4438-4444. [CrossRef]

23. Shitara, K.; Bang, Y.J.; Iwasa, S.; Sugimoto, N.; Ryu, M.H.; Sakai, D.; Chung, H.C.; Kawakami, H.; Yabusaki, H.; Lee, J.; et al. Trastuzumab deruxtecan in previously treated HER2-positive gastric cancer. N. Engl. J. Med. 2020, 382, 2419-2430. [CrossRef] [PubMed]

24. Shitara, K.; Doi, T.; Dvorkin, M.; Mansoor, W.; Arkenau, H.T.; Prokharau, A.; Alsina, M.; Ghidini, M.; Faustino, C.; Gorbunova, V.; et al. Trifluridine/tipiracil versus placebo in patients with heavily pretreated metastatic gastric cancer (TAGS): A randomised, double-blind, placebo-controlled, phase 3 trial. Lancet Oncol. 2018, 19, 1437-1448. [CrossRef]

25. Kang, Y.K.; Boku, N.; Satoh, T.; Ryu, M.H.; Chao, Y.; Kato, K.; Chung, H.C.; Chen, J.S.; Muro, K.; Kang, W.K.; et al. Nivolumab in patients with advanced gastric or gastro-oesophageal junction cancer refractory to, or intolerant of, at least two previous chemotherapy regimens (ONO-4538-12, ATTRACTION-2): A randomised, double-blind, placebo-controlled, phase 3 trial. Lancet 2017, 390, 2461-2471. [CrossRef]

26. Demetri, G.D.; von Mehren, M.; Blanke, C.D.; Van den Abbeele, A.D.; Eisenberg, B.; Roberts, P.J.; Heinrich, M.C.; Tuveson, D.A.; Singer, S.; Janicek, M.; et al. Efficacy and safety of imatinib mesylate in advanced gastrointestinal stromal tumors. N. Engl. J. Med. 2002, 347, 472-480. [CrossRef] [PubMed]

27. Demetri, G.D.; van Oosterom, A.T.; Garrett, C.R.; Blackstein, M.E.; Shah, M.H.; Verweij, J.; McArthur, G.; Judson, I.R.; Heinrich, M.C.; Morgan, J.A.; et al. Efficacy and safety of sunitinib in patients with advanced gastrointestinal stromal tumour after failure of imatinib: A randomised controlled trial. Lancet 2006, 368, 1329-1338. [CrossRef]

28. Demetri, G.D.; Reichardt, P.; Kang, Y.K.; Blay, J.Y.; Rutkowski, P.; Gelderblom, H.; Hohenberger, P.; Leahy, M.; von Mehren, M.; Joensuu, H.; et al. Efficacy and safety of regorafenib for advanced gastrointestinal stromal tumours after failure of imatinib and sunitinib (GRID): An international, multicentre, randomised, placebo-controlled, phase 3 trial. Lancet 2013, 381, 295-302. [CrossRef]

29. Bauer, S.; Heinrich, M.C.; George, S.; Zalcberg, J.R.; Serrano, C.; Gelderblom, H.; Jones, R.L.; Attia, S.; D’Amato, G.; Chi, P.; et al. Clinical activity of ripretinib in patients with advanced gastrointestinal stromal tumor harboring heterogenous KIT/PDGFRA mutations in the phase 3 INVICTUS study. Clin. Cancer Res. 2021, 27. [CrossRef] [PubMed]

30. Yao, J.C.; Shah, M.H.; Ito, T.; Bohas, C.L.; Wolin, E.M.; Van Cutsem, E.; Hobday, T.J.; Okusaka, T.; Capdevila, J.; de Vries, E.G.; et al. Everolimus for advanced pancreatic neuroendocrine tumors. N. Engl. J. Med. 2011, 364, 514-523. [CrossRef]

31. Raymond, E.; Dahan, L.; Raoul, J.L.; Bang, Y.J.; Borbath, I.; Lombard-Bohas, C.; Valle, J.; Metrakos, P.; Smith, D.; Vinik, A.; et al. Sunitinib malate for the treatment of pancreatic neuroendocrine tumors. N. Engl. J. Med. 2011, 364, 501-513. [CrossRef]

32. Rinke, A.; Muller, H.H.; Schade-Brittinger, C.; Klose, K.J.; Barth, P.; Wied, M.; Mayer, C.; Aminossadati, B.; Pape, U.F.; Blaker, M.; et al. Placebo-controlled, double-blind, prospective, randomized study on the effect of octreotide LAR in the control of tumor growth in patients with metastatic neuroendocrine midgut tumors: A report from the PROMID Study Group. J. Clin. Oncol. 2009, 27, 4656-4663. [CrossRef] [PubMed]

33. Caplin, M.E.; Pavel, M.; Cwikla, J.B.; Phan, A.T.; Raderer, M.; Sedlackova, E.; Cadiot, G.; Wolin, E.M.; Capdevila, J.; Wall, L.; et al Lanreotide in metastatic enteropancreatic neuroendocrine tumors. N. Engl. J. Med. 2014, 371, 224-233. [CrossRef] [PubMed]

34. Finn, R.S.; Qin, S.; Ikeda, M.; Galle, P.R.; Ducreux, M.; Kim, T.Y.; Kudo, M.; Breder, V.; Merle, P.; Kaseb, A.O.; et al. Atezolizumab plus bevacizumab in unresectable hepatocellular carcinoma. N. Engl. J. Med. 2020, 382, 1894-1905. [CrossRef] [PubMed]

35. Llovet, J.M.; Ricci, S.; Mazzaferro, V.; Hilgard, P.; Gane, E.; Blanc, J.F.; de Oliveira, A.C.; Santoro, A.; Raoul, J.L.; Forner, A.; et al. Sorafenib in advanced hepatocellular carcinoma. N. Engl. J. Med. 2008, 359, 378-390. [CrossRef]

36. Cheng, A.L.; Kang, Y.K.; Chen, Z.; Tsao, C.J.; Qin, S.; Kim, J.S.; Luo, R.; Feng, J.; Ye, S.; Yang, T.S.; et al. Efficacy and safety of sorafenib in patients in the Asia-Pacific region with advanced hepatocellular carcinoma: A phase III randomised, double-blind, placebo-controlled trial. Lancet Oncol. 2009, 10, 25-34. [CrossRef]

37. Kudo, M.; Finn, R.S.; Qin, S.; Han, K.H.; Ikeda, K.; Piscaglia, F.; Baron, A.; Park, J.W.; Han, G.; Jassem, J.; et al. Lenvatinib versus sorafenib in first-line treatment of patients with unresectable hepatocellular carcinoma: A randomised phase 3 non-inferiority trial. Lancet 2018, 391, 1163-1173. [CrossRef]

38. Bruix, J.; Qin, S.; Merle, P.; Granito, A.; Huang, Y.H.; Bodoky, G.; Pracht, M.; Yokosuka, O.; Rosmorduc, O.; Breder, V.; et al. Regorafenib for patients with hepatocellular carcinoma who progressed on sorafenib treatment (RESORCE): A randomised, double-blind, placebo-controlled, phase 3 trial. Lancet 2017, 389, 56-66. [CrossRef] 
39. Abou-Alfa, G.K.; Meyer, T.; Cheng, A.L.; El-Khoueiry, A.B.; Rimassa, L.; Ryoo, B.Y.; Cicin, I.; Merle, P.; Chen, Y.; Park, J.W.; et al. Cabozantinib in patients with advanced and progressing hepatocellular carcinoma. N. Engl. J. Med. 2018, 379, 54-63. [CrossRef]

40. Zhu, A.X.; Kang, Y.K.; Yen, C.J.; Finn, R.S.; Galle, P.R.; Llovet, J.M.; Assenat, E.; Brandi, G.; Pracht, M.; Lim, H.Y.; et al. Ramucirumab after sorafenib in patients with advanced hepatocellular carcinoma and increased alpha-fetoprotein concentrations (REACH-2): A randomised, double-blind, placebo-controlled, phase 3 trial. Lancet Oncol. 2019, 20, 282-296. [CrossRef]

41. Valle, J.; Wasan, H.; Palmer, D.H.; Cunningham, D.; Anthoney, A.; Maraveyas, A.; Madhusudan, S.; Iveson, T.; Hughes, S.; Pereira, S.P.; et al. Cisplatin plus gemcitabine versus gemcitabine for biliary tract cancer. N. Engl. J. Med. 2010, 362, 1273-1281. [CrossRef]

42. Morizane, C.; Okusaka, T.; Mizusawa, J.; Katayama, H.; Ueno, M.; Ikeda, M.; Ozaka, M.; Okano, N.; Sugimori, K.; Fukutomi, A.; et al. Combination gemcitabine plus S-1 versus gemcitabine plus cisplatin for advanced/recurrent biliary tract cancer: The FUGA-BT (JCOG1113) randomized phase III clinical trial. Ann. Oncol. 2019, 30, 1950-1958. [CrossRef] [PubMed]

43. Abou-Alfa, G.K.; Sahai, V.; Hollebecque, A.; Vaccaro, G.; Melisi, D.; Al-Rajabi, R.; Paulson, A.S.; Borad, M.J.; Gallinson, D.; Murphy, A.G.; et al. Pemigatinib for previously treated, locally advanced or metastatic cholangiocarcinoma: A multicentre, open-label, phase 2 study. Lancet Oncol. 2020, 21, 671-684. [CrossRef]

44. Conroy, T.; Desseigne, F.; Ychou, M.; Bouche, O.; Guimbaud, R.; Becouarn, Y.; Adenis, A.; Raoul, J.L.; Gourgou-Bourgade, S.; de la Fouchardiere, C.; et al. FOLFIRINOX versus gemcitabine for metastatic pancreatic cancer. N. Engl. J. Med. 2011, 364, 1817-1825. [CrossRef]

45. Von Hoff, D.D.; Ervin, T.; Arena, F.P.; Chiorean, E.G.; Infante, J.; Moore, M.; Seay, T.; Tjulandin, S.A.; Ma, W.W.; Saleh, M.N.; et al. Increased survival in pancreatic cancer with nab-paclitaxel plus gemcitabine. N. Engl. J. Med. 2013, 369, 1691-1703. [CrossRef] [PubMed]

46. Moore, M.J.; Goldstein, D.; Hamm, J.; Figer, A.; Hecht, J.R.; Gallinger, S.; Au, H.J.; Murawa, P.; Walde, D.; Wolff, R.A.; et al Erlotinib plus gemcitabine compared with gemcitabine alone in patients with advanced pancreatic cancer: A phase III trial of the National Cancer Institute of Canada Clinical Trials Group. J. Clin. Oncol. 2007, 25, 1960-1966. [CrossRef]

47. Golan, T.; Hammel, P.; Reni, M.; Van Cutsem, E.; Macarulla, T.; Hall, M.J.; Park, J.O.; Hochhauser, D.; Arnold, D.; Oh, D.Y.; et al Maintenance olaparib for germline BRCA-mutated metastatic pancreatic cancer. N. Engl. J. Med. 2019, 381, 317-327. [CrossRef] [PubMed]

48. Wang-Gillam, A.; Li, C.P.; Bodoky, G.; Dean, A.; Shan, Y.S.; Jameson, G.; Macarulla, T.; Lee, K.H.; Cunningham, D.; Blanc, J.F.; et al. Nanoliposomal irinotecan with fluorouracil and folinic acid in metastatic pancreatic cancer after previous gemcitabine-based therapy (NAPOLI-1): A global, randomised, open-label, phase 3 trial. Lancet 2016, 387, 545-557. [CrossRef]

49. de Gramont, A.; Figer, A.; Seymour, M.; Homerin, M.; Hmissi, A.; Cassidy, J.; Boni, C.; Cortes-Funes, H.; Cervantes, A.; Freyer, G.; et al. Leucovorin and fluorouracil with or without oxaliplatin as first-line treatment in advanced colorectal cancer. J. Clin. Oncol. 2000, 18, 2938-2947. [CrossRef]

50. Douillard, J.Y.; Siena, S.; Cassidy, J.; Tabernero, J.; Burkes, R.; Barugel, M.; Humblet, Y.; Bodoky, G.; Cunningham, D.; Jassem, J.; et al. Randomized, phase III trial of panitumumab with infusional fluorouracil, leucovorin, and oxaliplatin (FOLFOX4) versus FOLFOX4 alone as first-line treatment in patients with previously untreated metastatic colorectal cancer: The PRIME study. J. Clin. Oncol. 2010, 28, 4697-4705. [CrossRef]

51. Heinemann, V.; von Weikersthal, L.F.; Decker, T.; Kiani, A.; Vehling-Kaiser, U.; Al-Batran, S.E.; Heintges, T.; Lerchenmüller, C.; Kahl, C.; Seipelt, G.; et al. FOLFIRI plus cetuximab versus FOLFIRI plus bevacizumab as first-line treatment for patients with metastatic colorectal cancer (FIRE-3): A randomised, open-label, phase 3 trial. Lancet Oncol. 2014, 15, 1065-1075. [CrossRef]

52. Cremolini, C.; Loupakis, F.; Antoniotti, C.; Lupi, C.; Sensi, E.; Lonardi, S.; Mezi, S.; Tomasello, G.; Ronzoni, M.; Zaniboni, A.; et al. FOLFOXIRI plus bevacizumab versus FOLFIRI plus bevacizumab as first-line treatment of patients with metastatic colorectal cancer: Updated overall survival and molecular subgroup analyses of the open-label, phase 3 TRIBE study. Lancet Oncol. 2015, 16, 1306-1315. [CrossRef]

53. Cunningham, D.; Lang, I.; Marcuello, E.; Lorusso, V.; Ocvirk, J.; Shin, D.B.; Jonker, D.; Osborne, S.; Andre, N.; Waterkamp, D.; et al. Bevacizumab plus capecitabine versus capecitabine alone in elderly patients with previously untreated metastatic colorectal cancer (AVEX): An open-label, randomised phase 3 trial. Lancet Oncol. 2013, 14, 1077-1085. [CrossRef]

54. Andre, T.; Shiu, K.K.; Kim, T.W.; Jensen, B.V.; Jensen, L.H.; Punt, C.; Smith, D.; Garcia-Carbonero, R.; Benavides, M.; Gibbs, P.; et al. Pembrolizumab in microsatellite-instability-high advanced colorectal cancer. N. Engl. J. Med. 2020, 383, 2207-2218. [CrossRef] [PubMed]

55. Peeters, M.; Price, T.J.; Cervantes, A.; Sobrero, A.F.; Ducreux, M.; Hotko, Y.; André, T.; Chan, E.; Lordick, F.; Punt, C.J.; et al. Randomized phase III study of panitumumab with fluorouracil, leucovorin, and irinotecan (FOLFIRI) compared with FOLFIRI alone as second-line treatment in patients with metastatic colorectal cancer. J. Clin. Oncol. 2010, 28, 4706-4713. [CrossRef]

56. Tabernero, J.; Yoshino, T.; Cohn, A.L.; Obermannova, R.; Bodoky, G.; Garcia-Carbonero, R.; Ciuleanu, T.E.; Portnoy, D.C.; Van Cutsem, E.; Grothey, A.; et al. Ramucirumab versus placebo in combination with second-line FOLFIRI in patients with metastatic colorectal carcinoma that progressed during or after first-line therapy with bevacizumab, oxaliplatin, and a fluoropyrimidine (RAISE): A randomised, double-blind, multicentre, phase 3 study. Lancet Oncol. 2015, 16, 499-508. [CrossRef]

57. Van Cutsem, E.; Tabernero, J.; Lakomy, R.; Prenen, H.; Prausová, J.; Macarulla, T.; Ruff, P.; van Hazel, G.A.; Moiseyenko, V.; Ferry, D.; et al. Addition of aflibercept to fluorouracil, leucovorin, and irinotecan improves survival in a phase III randomized trial in patients with metastatic colorectal cancer previously treated with an oxaliplatin-based regimen. J. Clin. Oncol. 2012, 30, 3499-3506. [CrossRef] 
58. Overman, M.J.; Lonardi, S.; Wong, K.Y.M.; Lenz, H.J.; Gelsomino, F.; Aglietta, M.; Morse, M.A.; Van Cutsem, E.; McDermott, R.; Hill, A.; et al. Durable clinical benefit with nivolumab plus ipilimumab in DNA mismatch repair-deficient/microsatellite instability-high metastatic colorectal cancer. J. Clin. Oncol. 2018, 36, 773-779. [CrossRef]

59. Kopetz, S.; Grothey, A.; Yaeger, R.; Van Cutsem, E.; Desai, J.; Yoshino, T.; Wasan, H.; Ciardiello, F.; Loupakis, F.; Hong, Y.S.; et al. Encorafenib, Binimetinib, and Cetuximab in BRAF V600E-Mutated Colorectal Cancer. N. Engl. J. Med. 2019, 381, 1632-1643. [CrossRef]

60. Cunningham, D.; Humblet, Y.; Siena, S.; Khayat, D.; Bleiberg, H.; Santoro, A.; Bets, D.; Mueser, M.; Harstrick, A.; Verslype, C.; et al. Cetuximab monotherapy and cetuximab plus irinotecan in irinotecan-refractory metastatic colorectal cancer. N. Engl. J. Med. 2004, 351, 337-345. [CrossRef]

61. Mayer, R.J.; Van Cutsem, E.; Falcone, A.; Yoshino, T.; Garcia-Carbonero, R.; Mizunuma, N.; Yamazaki, K.; Shimada, Y.; Tabernero, J.; Komatsu, Y.; et al. Randomized trial of TAS-102 for refractory metastatic colorectal cancer. N. Engl. J. Med. 2015, 372, 1909-1919. [CrossRef]

62. Grothey, A.; Van Cutsem, E.; Sobrero, A.; Siena, S.; Falcone, A.; Ychou, M.; Humblet, Y.; Bouche, O.; Mineur, L.; Barone, C.; et al. Regorafenib monotherapy for previously treated metastatic colorectal cancer (CORRECT): An international, multicentre, randomised, placebo-controlled, phase 3 trial. Lancet 2013, 381, 303-312. [CrossRef]

63. Drilon, A.; Laetsch, T.W.; Kummar, S.; DuBois, S.G.; Lassen, U.N.; Demetri, G.D.; Nathenson, M.; Doebele, R.C.; Farago, A.F.; Pappo, A.S.; et al. Efficacy of Larotrectinib in TRK fusion-positive cancers in adults and children. N. Engl. J. Med. 2018, 378, 731-739. [CrossRef] [PubMed]

64. Doebele, R.C.; Drilon, A.; Paz-Ares, L.; Siena, S.; Shaw, A.T.; Farago, A.F.; Blakely, C.M.; Seto, T.; Cho, B.C.; Tosi, D.; et al Entrectinib in patients with advanced or metastatic NTRK fusion-positive solid tumours: Integrated analysis of three phase 1-2 trials. Lancet Oncol. 2020, 21, 271-282. [CrossRef]

65. Marabelle, A.; Le, D.T.; Ascierto, P.A.; Di Giacomo, A.M.; De Jesus-Acosta, A.; Delord, J.P.; Geva, R.; Gottfried, M.; Penel, N.; Hansen, A.R.; et al. Efficacy of pembrolizumab in patients with noncolorectal high microsatellite instability/mismatch repair-deficient cancer: Results from the Phase II KEYNOTE-158 study. J. Clin. Oncol. 2020, 38, 1-10. [CrossRef] [PubMed]

66. Malet-Martino, M.; Martino, R. Clinical studies of three oral prodrugs of 5-fluorouracil (capecitabine, UFT, S-1): A review. Oncologist 2002, 7, 288-323. [CrossRef] [PubMed]

67. Abdel-Rahman, O.; ElHalawani, H.; Essam-Eldin, S. S-1-based regimens and the risk of oral and gastrointestinal mucosal injury: A meta-analysis with comparison to other fluoropyrimidines. Expert Opin. Drug Saf. 2016, 15, 5-20. [CrossRef] [PubMed]

68. Ter Veer, E.; Ngai, L.L.; Valkenhoef, G.V.; Mohammad, N.H.; Anderegg, M.C.J.; van Oijen, M.G.H.; van Laarhoven, H.W.M. Capecitabine, 5-fluorouracil and S-1 based regimens for previously untreated advanced oesophagogastric cancer: A network meta-analysis. Sci. Rep. 2017, 7, 7142. [CrossRef]

69. Schwab, M.; Zanger, U.M.; Marx, C.; Schaeffeler, E.; Klein, K.; Dippon, J.; Kerb, R.; Blievernicht, J.; Fischer, J.; Hofmann, U.; et al Role of genetic and nongenetic factors for fluorouracil treatment-related severe toxicity: A prospective clinical trial by the German 5-FU Toxicity Study Group. J. Clin. Oncol. 2008, 26, 2131-2138. [CrossRef]

70. Saltz, L.B.; Douillard, J.Y.; Pirotta, N.; Alakl, M.; Gruia, G.; Awad, L.; Elfring, G.L.; Locker, P.K.; Miller, L.L. Irinotecan plus fluorouracil/leucovorin for metastatic colorectal cancer: A new survival standard. Oncologist 2001, 6, 81-91. [CrossRef]

71. Sharif, S.; O'Connell, M.J.; Yothers, G.; Lopa, S.; Wolmark, N. FOLFOX and FLOX regimens for the adjuvant treatment of resected stage II and III colon cancer. Cancer Investig. 2008, 26, 956-963. [CrossRef]

72. Raida, M.; Schwabe, W.; Häusler, P.; Van Kuilenburg, A.B.; Van Gennip, A.H.; Behnke, D.; Höffken, K. Prevalence of a common point mutation in the dihydropyrimidine dehydrogenase (DPD) gene within the $5^{\prime}$-splice donor site of intron 14 in patients with severe 5-fluorouracil (5-FU)- related toxicity compared with controls. Clin. Cancer Res. 2001, 7, 2832-2839. [PubMed]

73. Pritchard, D.M.; Potten, C.S.; Hickman, J.A. The relationships between p53-dependent apoptosis, inhibition of proliferation, and 5-fluorouracil-induced histopathology in murine intestinal epithelia. Cancer Res. 1998, 58, 5453-5465. [PubMed]

74. Lee, C.S.; Ryan, E.J.; Doherty, G.A. Gastro-intestinal toxicity of chemotherapeutics in colorectal cancer: The role of inflammation World J. Gastroenterol. 2014, 20, 3751-3761. [CrossRef] [PubMed]

75. Logan, R.M.; Stringer, A.M.; Bowen, J.M.; Gibson, R.J.; Sonis, S.T.; Keefe, D.M. Is the pathobiology of chemotherapy-induced alimentary tract mucositis influenced by the type of mucotoxic drug administered? Cancer Chemother. Pharmacol. 2009, 63, 239-251. [CrossRef]

76. Chang, C.T.; Ho, T.Y.; Lin, H.; Liang, J.A.; Huang, H.C.; Li, C.C.; Lo, H.Y.; Wu, S.L.; Huang, Y.F.; Hsiang, C.Y. 5-Fluorouracil induced intestinal mucositis via nuclear factor-kappaB activation by transcriptomic analysis and in vivo bioluminescence imaging. PLoS ONE 2012, 7, e31808. [CrossRef]

77. Sakumura, M.; Ando, T.; Hosokawa, A.; Nakajima, T.; Motoo, I.; Mihara, H.; Ueda, A.; Kajiura, S.; Nanjo, S.; Fujinami, H.; et al. Small intestinal mucosal injury and its risk factors in patients with gastrointestinal cancer who developed complicated fluoropyrimidine-induced diarrhea. BMC Gastroenterol. 2020, 20, 355. [CrossRef]

78. Dancey, J.; Eisenhauer, E.A. Current perspectives on camptothecins in cancer treatment. Br. J. Cancer 1996, 74, 327-338. [CrossRef]

79. Kawato, Y.; Aonuma, M.; Hirota, Y.; Kuga, H.; Sato, K. Intracellular roles of SN-38, a metabolite of the camptothecin derivative CPT-11, in the antitumor effect of CPT-11. Cancer Res. 1991, 51, 4187-4191.

80. Iyer, L.; Das, S.; Janisch, L.; Wen, M.; Ramírez, J.; Karrison, T.; Fleming, G.F.; Vokes, E.E.; Schilsky, R.L.; Ratain, M.J. UGT1A1*28 polymorphism as a determinant of irinotecan disposition and toxicity. Pharmacogenom. J. 2002, 2, 43-47. [CrossRef] 
81. Ichikawa, W.; Uehara, K.; Minamimura, K.; Tanaka, C.; Takii, Y.; Miyauchi, H.; Sadahiro, S.; Fujita, K.; Moriwaki, T.; Nakamura, M.; et al. An internally and externally validated nomogram for predicting the risk of irinotecan-induced severe neutropenia in advanced colorectal cancer patients. Br. J. Cancer 2015, 112, 1709-1716. [CrossRef]

82. Innocenti, F.; Undevia, S.D.; Iyer, L.; Chen, P.X.; Das, S.; Kocherginsky, M.; Karrison, T.; Janisch, L.; Ramírez, J.; Rudin, C.M.; et al. Genetic variants in the UDP-glucuronosyltransferase 1A1 gene predict the risk of severe neutropenia of irinotecan. J. Clin. Oncol. 2004, 22, 1382-1388. [CrossRef] [PubMed]

83. Saliba, F.; Hagipantelli, R.; Misset, J.L.; Bastian, G.; Vassal, G.; Bonnay, M.; Herait, P.; Cote, C.; Mahjoubi, M.; Mignard, D.; et al. Pathophysiology and therapy of irinotecan-induced delayed-onset diarrhea in patients with advanced colorectal cancer: A prospective assessment. J. Clin. Oncol. 1998, 16, 2745-2751. [CrossRef] [PubMed]

84. Stringer, A.M.; Gibson, R.J.; Logan, R.M.; Bowen, J.M.; Yeoh, A.S.; Keefe, D.M. Faecal microflora and beta-glucuronidase expression are altered in an irinotecan-induced diarrhea model in rats. Cancer Biol. Ther. 2008, 7, 1919-1925. [CrossRef] [PubMed]

85. Danielsen, A.J.; Maihle, N.J. The EGF/ErbB receptor family and apoptosis. Growth Factors 2002, 20, 1-15. [CrossRef]

86. Weidner, N.; Semple, J.P.; Welch, W.R.; Folkman, J. Tumor angiogenesis and metastasis-Correlation in invasive breast carcinoma. N. Engl. J. Med. 1991, 324, 1-8. [CrossRef]

87. Fabian, M.A.; Biggs, W.H., 3rd; Treiber, D.K.; Atteridge, C.E.; Azimioara, M.D.; Benedetti, M.G.; Carter, T.A.; Ciceri, P.; Edeen, P.T.; Floyd, M.; et al. A small molecule-kinase interaction map for clinical kinase inhibitors. Nat. Biotechnol. 2005, 23, 329-336. [CrossRef]

88. Manning, G.; Whyte, D.B.; Martinez, R.; Hunter, T.; Sudarsanam, S. The protein kinase complement of the human genome. Science 2002, 298, 1912-1934. [CrossRef]

89. Bowen, J.M. Mechanisms of TKI-induced diarrhea in cancer patients. Curr. Opin. Support. Palliat. Care 2013, 7, 162-167. [CrossRef]

90. Van Cutsem, E.; Peeters, M.; Siena, S.; Humblet, Y.; Hendlisz, A.; Neyns, B.; Canon, J.L.; Van Laethem, J.L.; Maurel, J.; Richardson, G.; et al. Open-label phase III trial of panitumumab plus best supportive care compared with best supportive care alone in patients with chemotherapy-refractory metastatic colorectal cancer. J. Clin. Oncol. 2007, 25, 1658-1664. [CrossRef]

91. Davila, M.; Bresalier, R.S. Gastrointestinal complications of oncologic therapy. Nat. Clin. Pract. Gastroenterol. Hepatol. 2008, 5, 682-696. [CrossRef]

92. Vincenzi, B.; Schiavon, G.; Pantano, F.; Santini, D.; Tonini, G. Predictive factors for chemotherapy-related toxic effects in patients with colorectal cancer. Nat. Clin. Pract. Oncol. 2008, 5, 455-465. [CrossRef] [PubMed]

93. Secombe, K.R.; Van Sebille, Y.Z.A.; Mayo, B.J.; Coller, J.K.; Gibson, R.J.; Bowen, J.M. Diarrhea induced by small molecule tyrosine kinase inhibitors compared with chemotherapy: Potential role of the microbiome. Integr. Cancer Ther. 2020, 19, 1534735420928493. [CrossRef] [PubMed]

94. Date, E.; Okamoto, K.; Fumita, S.; Kaneda, H. Gastrointestinal perforation related to lenvatinib, an anti-angiogenic inhibitor that targets multiple receptor tyrosine kinases, in a patient with metastatic thyroid cancer. Investig. New Drugs 2018, 36, 350-353. [CrossRef] [PubMed]

95. Frieling, T.; Heise, J.; Wassilew, S.W. Multiple colon ulcerations, perforation and death during treatment of malignant melanoma with sorafenib. Dtsch. Med. Wochenschr. 2009, 134, e1-e2. [CrossRef] [PubMed]

96. Wang, D.Y.; Ye, F.; Zhao, S.; Johnson, D.B. Incidence of immune checkpoint inhibitor-related colitis in solid tumor patients: A systematic review and meta-analysis. Oncoimmunology 2017, 6, e1344805. [CrossRef] [PubMed]

97. Marthey, L.; Mateus, C.; Mussini, C.; Nachury, M.; Nancey, S.; Grange, F.; Zallot, C.; Peyrin-Biroulet, L.; Rahier, J.F.; Bourdier de Beauregard, M.; et al. Cancer immunotherapy with anti-CTLA-4 monoclonal antibodies induces an inflammatory bowel disease. J. Crohns. Colitis 2016, 10, 395-401. [CrossRef]

98. Beck, K.E.; Blansfield, J.A.; Tran, K.Q.; Feldman, A.L.; Hughes, M.S.; Royal, R.E.; Kammula, U.S.; Topalian, S.L.; Sherry, R.M.; Kleiner, D.; et al. Enterocolitis in patients with cancer after antibody blockade of cytotoxic T-lymphocyte-associated antigen 4 . J. Clin. Oncol. 2006, 24, 2283-2289. [CrossRef]

99. Verschuren, E.C.; van den Eertwegh, A.J.; Wonders, J.; Slangen, R.M.; van Delft, F.; van Bodegraven, A.; Neefjes-Borst, A.; de Boer, N.K. Clinical, endoscopic, and histologic characteristics of ipilimumab-associated colitis. Clin. Gastroenterol. Hepatol. 2016, 14, 836-842. [CrossRef]

100. Jain, A.; Lipson, E.J.; Sharfman, W.H.; Brant, S.R.; Lazarev, M.G. Colonic ulcerations may predict steroid-refractory course in patients with ipilimumab-mediated enterocolitis. World J. Gastroenterol. 2017, 23, 2023-2028. [CrossRef]

101. Collins, M.; Michot, J.M.; Danlos, F.X.; Mussini, C.; Soularue, E.; Mateus, C.; Loirat, D.; Buisson, A.; Rosa, I.; Lambotte, O.; et al. Inflammatory gastrointestinal diseases associated with PD-1 blockade antibodies. Ann. Oncol. 2017, 28, 2860-2865. [CrossRef]

102. Gonzalez, R.S.; Salaria, S.N.; Bohannon, C.D.; Huber, A.R.; Feely, M.M.; Shi, C. PD-1 inhibitor gastroenterocolitis: Case series and appraisal of 'immunomodulatory gastroenterocolitis'. Histopathology 2017, 70, 558-567. [CrossRef] [PubMed]

103. Wang, D.Y.; Mooradian, M.J.; Kim, D.; Shah, N.J.; Fenton, S.E.; Conry, R.M.; Mehta, R.; Silk, A.W.; Zhou, A.; Compton, M.L.; et al Clinical characterization of colitis arising from anti-PD-1 based therapy. Oncoimmunology 2019, 8, e1524695. [CrossRef] [PubMed]

104. Cheung, V.T.F.; Gupta, T.; Olsson-Brown, A.; Subramanian, S.; Sasson, S.C.; Heseltine, J.; Fryer, E.; Collantes, E.; Sacco, J.J.; Pirmohamed, M.; et al. Immune checkpoint inhibitor-related colitis assessment and prognosis: Can IBD scoring point the way? Br. J. Cancer 2020, 123, 207-215. [CrossRef] [PubMed] 
105. Powell, N.; Ibraheim, H.; Raine, T.; Speight, R.A.; Papa, S.; Brain, O.; Green, M.; Samaan, M.A.; Spain, L.; Yousaf, N.; et al. British Society of Gastroenterology endorsed guidance for the management of immune checkpoint inhibitor-induced enterocolitis. Lancet Gastroenterol. Hepatol. 2020, 5, 679-697. [CrossRef]

106. Puzanov, I.; Diab, A.; Abdallah, K.; Bingham, C.O., 3rd; Brogdon, C.; Dadu, R.; Hamad, L.; Kim, S.; Lacouture, M.E.; LeBoeuf, N.R.; et al. Managing toxicities associated with immune checkpoint inhibitors: Consensus recommendations from the Society for Immunotherapy of Cancer (SITC) Toxicity Management Working Group. J. Immunother. Cancer 2017, 5, 95. [CrossRef]

107. Haanen, J.; Carbonnel, F.; Robert, C.; Kerr, K.M.; Peters, S.; Larkin, J.; Jordan, K.; Committee, E.G. Management of toxicities from immunotherapy: ESMO Clinical Practice Guidelines for diagnosis; treatment and follow-up. Ann. Oncol. 2018, 29, iv264-iv266. [CrossRef]

108. Fata, F.; Ron, I.G.; Kemeny, N.; O’Reilly, E.; Klimstra, D.; Kelsen, D.P. 5-Fluorouracil-induced small bowel toxicity in patients with colorectal carcinoma. Cancer 1999, 86, 1129-1134. [CrossRef]

109. Yamasaki, T.; Sugito, M.; Yoshikawa, I.; Kume, K.; Narita, R.; Otsuki, M. Ileocecal ulcer caused by chemotherapy. Gastrointest. Endosc. 2002, 55, 411. [CrossRef]

110. Kuebler, J.P.; Colangelo, L.; O'Connell, M.J.; Smith, R.E.; Yothers, G.; Begovic, M.; Robinson, B.; Seay, T.E.; Wolmark, N. Severe enteropathy among patients with stage II/III colon cancer treated on a randomized trial of bolus 5-fluorouracil/leucovorin plus or minus oxaliplatin: A prospective analysis. Cancer 2007, 110, 1945-1950. [CrossRef]

111. Hosokawa, A.; Nishikawa, J.; Ando, T.; Sugiyama, T. Chemotherapy-induced small bowel injury. Intern. Med. 2016, 55, 1023. [CrossRef]

112. Ota, K.; Takeuchi, T.; Kodama, K.; Ozaki, H.; Harada, S.; Kojima, Y.; Nouda, S.; Goto, M.; Higuchi, K. The capsule endoscopy findings in s-1-induced enteritis with severe diarrhea during adjuvant chemotherapy for gastric cancer (with video). Intern. Med. 2018, 57, 343-344. [CrossRef] [PubMed]

113. Dore, M.P.; Pes, G.M.; Murino, A.; Quarta Colosso, B.; Pennazio, M. Short article: Small intestinal mucosal injury in patients taking chemotherapeutic agents for solid cancers. Eur. J. Gastroenterol. Hepatol. 2017, 29, 68-571. [CrossRef]

114. Malard, F.; Mohty, M. New insight for the diagnosis of gastrointestinal acute graft-versus-host disease. Mediat. Inflamm. 2014, 2014, 701013. [CrossRef] [PubMed]

115. Ota, K.; Takeuchi, T.; Kojima, Y.; Harada, S.; Ozaki, H.; Sugawara, N.; Hirata, Y.; Yamaguchi, T.; Terazawa, T.; Kakimoto, K.; et al. Fluoropyrimidine-induced intestinal mucosal injury is associated with the severity of chemotherapy-related diarrhea. Scand. J. Gastroenterol. 2019, 54, 227-232. [CrossRef]

116. Shimozaki, K.; Hirata, K.; Horie, S.; Chida, A.; Tsugaru, K.; Hayashi, Y.; Kawasaki, K.; Miyanaga, R.; Hayashi, H.; Mizuno, R.; et al. The entire intestinal tract surveillance using capsule endoscopy after immune checkpoint inhibitor administration: A prospective observational study. Diagnostics 2021, 11, 543. [CrossRef] [PubMed]

117. Cascinu, S.; Fedeli, A.; Fedeli, S.L.; Catalano, G. Octreotide versus loperamide in the treatment of fluorouracil-induced diarrhea: A randomized trial. J. Clin. Oncol. 1993, 11, 148-151. [CrossRef] [PubMed]

118. Geukes Foppen, M.H.; Rozeman, E.A.; van Wilpe, S.; Postma, C.; Snaebjornsson, P.; van Thienen, J.V.; van Leerdam, M.E.; van den Heuvel, M.; Blank, C.U.; van Dieren, J.; et al. Immune checkpoint inhibition-related colitis: Symptoms, endoscopic features, histology and response to management. ESMO Open 2018, 3, e000278. [CrossRef] [PubMed]

119. Abu-Sbeih, H.; Ali, F.S.; Alsaadi, D.; Jennings, J.; Luo, W.; Gong, Z.; Richards, D.M.; Charabaty, A.; Wang, Y. Outcomes of vedolizumab therapy in patients with immune checkpoint inhibitor-induced colitis: A multi-center study. J. Immunother. Cancer 2018, 6, 142. [CrossRef] [PubMed] 